Article

\title{
Tissue miRNA Combinations for the Differential Diagnosis of Adrenocortical Carcinoma and Adenoma Established by Artificial Intelligence
}

\author{
Péter István Turai ${ }^{1,2,3}\left(\mathbb{D}\right.$, Zoltán Herold ${ }^{4}\left(\mathbb{D}\right.$, Gábor Nyirő ${ }^{1,3,5}{ }^{(D)}$, Katalin Borka ${ }^{6}$, Tamás Micsik ${ }^{7}$, Judit Tóke ${ }^{1,2}$, \\ Nikolette Szücs ${ }^{1,2}$, Miklós Tóth ${ }^{1,2}(\mathbb{D}$, Attila Patócs $5,8,9$ (D) and Peter Igaz $1,2,3, *(\mathbb{D})$
}

Citation: Turai, P.I.; Herold, Z.; Nyirő, G.; Borka, K.; Micsik, T.;

Tóke, J.; Szücs, N.; Tóth, M.;

Patócs, A.; Igaz, P. Tissue miRNA Combinations for the Differential

Diagnosis of Adrenocortical

Carcinoma and Adenoma

Established by Artificial Intelligence.

Cancers 2022, 14, 895. https://

doi.org/10.3390/cancers14040895

Academic Editor: Guido Alberto

Massimo Tiberio

Received: 11 January 2022

Accepted: 7 February 2022

Published: 11 February 2022

Publisher's Note: MDPI stays neutral with regard to jurisdictional claims in published maps and institutional affiliations.

Copyright: (C) 2022 by the authors. Licensee MDPI, Basel, Switzerland. This article is an open access article distributed under the terms and conditions of the Creative Commons Attribution (CC BY) license (https:// creativecommons.org/licenses/by/ $4.0 /)$.
1 Department of Endocrinology, ENS@T Research Center of Excellence, Faculty of Medicine, Semmelweis University, H-1083 Budapest, Hungary; turai.peter_istvan@semmelweis-univ.hu (P.I.T.); nyiro.gabor1@med.semmelweis-univ.hu (G.N.); toke.judit@med.semmelweis-univ.hu (J.T.); szucs.nikolette@med.semmelweis-univ.hu (N.S.); toth.miklos@med.semmelweis-univ.hu (M.T.)

2 Department of Internal Medicine and Oncology, Faculty of Medicine, Semmelweis University, H-1083 Budapest, Hungary

3 MTA-SE Molecular Medicine Research Group, Eötvös Loránd Research Network, H-1083 Budapest, Hungary

4 Division of Oncology, Department of Internal Medicine and Oncology, Faculty of Medicine, Semmelweis University, H-1083 Budapest, Hungary; herold.zoltan@med.semmelweis-univ.hu

5 Department of Laboratory Medicine, Faculty of Medicine, Semmelweis University, H-1089 Budapest, Hungary; patocs.attila@med.semmelweis-univ.hu

6 2nd Department of Pathology, Semmelweis University, H-1091 Budapest, Hungary; borka.katalin@med.semmelweis-univ.hu

7 1st Department of Pathology and Experimental Cancer Research, Semmelweis University, H-1088 Budapest, Hungary; micsik.tamas@med.semmelweis-univ.hu

8 MTA-SE Hereditary Tumors Research Group, Eötvös Loránd Research Network, H-1122 Budapest, Hungary

9 Department of Molecular Genetics, National Institute of Oncology, H-1122 Budapest, Hungary

* Correspondence: igaz.peter@med.semmelweis-univ.hu; Tel.: +36-1-266-0816

Simple Summary: The histological differential diagnosis of adrenocortical adenoma and carcinoma is difficult and requires great expertise. MiRNAs were shown to be useful for the differential diagnosis of benign and malignant tumors of several organs, and several findings have suggested their utility in adrenocortical tumors as well. Here, we have selected tissue miRNAs based on the literature search, and used machine learning to identify novel clinically applicable miRNA combinations. Combinations with high sensitivity and specificity (both over $90 \%$ ) have been identified that could be promising for clinical use. Besides being a useful adjunct to histological examination, these miRNA combinations could enable preoperative adrenal biopsy in patients with adrenal tumors suspicious for malignancy.

Abstract: The histological analysis of adrenal tumors is difficult and requires great expertise. Tissue microRNA (miRNA) expression is distinct between benign and malignant tumors of several organs and can be useful for diagnostic purposes. MiRNAs are stable and their expression can be reliably reproduced from archived formalin-fixed, paraffin-embedded (FFPE) tissue blocks. Our purpose was to assess the potential applicability of combinations of literature-based miRNAs as markers of adrenocortical malignancy. Archived FFPE tissue samples from 10 adrenocortical carcinoma (ACC), 10 adrenocortical adenoma (ACA) and 10 normal adrenal cortex samples were analyzed in a discovery cohort, while 21 ACC and 22 ACA patients were studied in a blind manner in the validation cohort. The expression of miRNA was determined by RT-qPCR. Machine learning and neural network-based methods were used to find the best performing miRNA combination models. To evaluate diagnostic applicability, ROC-analysis was performed. We have identified three miRNA combinations (hsa-miR-195 + hsa-miR-210 + hsa-miR-503; hsa-miR-210 + hsa-miR-375 + hsa-miR-503 and $h s a-m i R-210+h s a-m i R-483-5 p+h s a-m i R-503)$ as unexpectedly good predictors to determine adrenocortical malignancy with sensitivity and specificity both of over $90 \%$. These miRNA panels can supplement the histological examination of removed tumors and could even be performed from small volume adrenal biopsy samples preoperatively. 
Keywords: adrenocortical carcinoma; adenoma; adrenal; tissue; microRNA; biomarker; artificial intelligence; neural network

\section{Introduction}

Adrenal tumors are relatively frequent with a prevalence of $4.2 \%$ in high-resolution abdominal imaging studies [1]. Among adrenocortical tumors, adrenocortical carcinoma (ACC) has a poor prognosis, as less than a third of the patients survive at least 5 years [2-4]. Although ACC is the rarest among adrenal tumors, with an annual incidence of $0.7-2 / \mathrm{million}$, it is included in the differential diagnosis of any incidentally discovered adrenal mass [3]. Adrenocortical adenoma (ACA) is the most frequent diagnosis (49-69\% in surgical series) among adrenal tumors [5]. In addition to tumors of the adrenal cortex, myelolipoma, which is invariably benign and contains fat and bone marrow elements, and pheochromocytoma, of an adrenal medullary origin causing severe blood pressure fluctuations, may also occur [5]. Adrenal glands often harbor metastasis from distinct malignancies; moreover, adrenocortical hyperplasia, adrenal cyst, adrenal hemorrhage, and, very rarely, adrenal lymphoma and adrenal tuberculosis should also be kept in mind as potential adrenal pathologies [6]. The differentiation of adrenocortical adenoma and carcinoma is often challenging.

Medical imaging is especially helpful in establishing the diagnosis of adrenocortical malignancy. Tumor size, density, heterogeneity, irregular borders and necrosis are assessed on CT (computed tomography), and there are also options for further imaging, e.g., washout CT, MRI (magnetic resonance imaging) or ${ }^{18}$ FDG-PET-CT $\left({ }^{18}\right.$ fluorodeoxygluco se-positron emission tomography-CT) [5]. Still there is no preoperative blood-borne molecular marker of malignancy. Urinary steroid metabolomics can be helpful [7], but it is not widely available.

The histological examination of adrenal tumors (including the Weiss-score and modified Weiss-score) is difficult and requires great expertise. Moreover, significant interobserver variability and a lack of accuracy in borderline cases are known limitations [8]. Mainly due to the difficulty of histological examinations, a biopsy of adrenal tumors is not recommended in routine practice and according to the current guidelines [3,5], as it would be difficult to determine malignancy from a small amount of tissue obtained, and there is a potential risk of complications (bleeding, pneumothorax) and maybe tumor dissemination as well $[9,10]$. The risk of complications linked to adrenal biopsy is not very high $(2.5 \%)$, but it has only a sensitivity of $70 \%$ for diagnosing ACC [11,12].

For all these reasons there is a great need for additional markers that can help determine the biological behavior of adrenocortical tumors.

MicroRNAs (miRNA, miR) have long been one of the cornerstones of biomarker research [13]. MiRNAs are 19-25 nucleotide long evolutionary conserved single stranded non-coding RNA molecules, most often encoded by their own genes. MiRNAs are the epigenetic regulators of RNA interference as they regulate up to $30-60 \%$ of human genes at the post-transcriptional level—without altering the very sequence of DNA [14].

miRNAs exert their inhibitory functions on translation via binding to the $3^{\prime}$ untranslated region (UTR) of their target mRNA in the cytoplasm [15]. Besides, it was shown that miRNAs might act within the cell nucleus by the modification of histone proteins and transcription itself [16]. Biological functions of miRNAs have been characterized from abundant sources [17-19]. In tumors, both overexpressed (oncogenic) and underexpressed (tumor suppressor), miRNAs are known for acting in a tissue specific fashion [20-22]. From a biomarker research point of view the two most important features of miRNAs are their exceptional stability and reproducibility from fresh frozen tissue, FFPE (formalinfixed, paraffin-embedded) samples or even from biofluids (e.g., from blood), and their marked tissue/cell and disease specificity $[23,24]$. Currently, there are about 2500 known 
human miRNAs and only a minor part of them has been described in the pathogenesis of adrenocortical tumors [25-29].

The long-lasting quest for a legit biomarker of adrenocortical carcinoma set our research group to design novel miRNA combination panels as markers of malignancy. Based on the current literature and bolstered by the state-of-art biostatistics tools, such as artificial intelligence (AI) implemented through machine learning and neural networks, our aim was to establish miRNA models with high sensitivity and specificity applicable for clinical use.

\section{Materials and Methods}

\subsection{Tissue Collection and Ethics Approval}

A total of 31 ACC, 32 ACA (Table 1) and 10 normal adrenal cortex (NAC) FFPE samples were recruited in the study. NAC samples were included only to investigate whether there are differences in the expression of the selected microRNAs between normal, benign, and malignant adrenocortical tissues. All samples were histologically confirmed by adrenal expert pathologists. Only specific parts of the blocks were dissected for RNA isolation. NAC samples were obtained from patients undergoing total nephrectomy for kidney tumors (females: 5, males: 5, mean age: 36.2 and 55.8, respectively). The discovery cohort was comprised of $10 \mathrm{ACA}, 10 \mathrm{ACC}, 10 \mathrm{NAC}$ and the independent validation cohort contained another 21 ACC and 22 ACA FFPE samples (Table S1).

Table 1. Clinical and main pathological characteristics of the tumor samples included. F: female, M: male, NF: non-functioning, DHEAS: dehydroepiandrosterone sulfate, DOC: 11-Deoxycorticosterone, ND: no data.

\begin{tabular}{|c|c|c|c|c|c|c|}
\hline Cohort/Samples & Sex & $\begin{array}{l}\text { Mean Age at } \\
\text { Sample Taking } \\
\text { (Years) }\end{array}$ & $\begin{array}{l}\text { Mean Tumor } \\
\text { Size }(\mathrm{mm})\end{array}$ & Ki-67 (\%) & ENSAT Stage & Hormonal Activity \\
\hline Discovery ACA & $10 \mathrm{~F}$ & 47.5 & 33.9 & - & - & $\begin{array}{c}7 \text { cortisol } \\
3 \mathrm{NF} \\
3 \text { cortisol }\end{array}$ \\
\hline Discovery ACC & $\begin{array}{c}6 \mathrm{~F} \\
4 \mathrm{M}\end{array}$ & 45.2 & 96.2 & $10-15(1-40)$ & $\begin{array}{l}5 \mathrm{II} \\
5 \mathrm{III}\end{array}$ & $\begin{array}{c}5 \mathrm{NF} \\
1 \mathrm{DOC} \\
1 \mathrm{DOC}+\text { cortisol + estradiol }\end{array}$ \\
\hline Validation ACA & $\begin{array}{l}17 \mathrm{~F} \\
5 \mathrm{M}\end{array}$ & 53.9 & 35 & - & - & $\begin{array}{c}11 \text { cortisol } \\
10 \mathrm{NF} \\
1 \text { DHEAS }\end{array}$ \\
\hline Validation ACC & $\begin{array}{l}14 \mathrm{~F} \\
7 \mathrm{M}\end{array}$ & 55.4 & 102 & $25-30(8-50)$ & $\begin{array}{c}1 \mathrm{I} \\
4 \mathrm{II} \\
5 \mathrm{III} \\
11 \mathrm{IV}\end{array}$ & $\begin{array}{c}7 \text { cortisol } \\
11 \mathrm{NF} \\
2 \text { cortisol + DHEAS } \\
1 \text { cortisol + androgen }\end{array}$ \\
\hline
\end{tabular}

The study was approved by the Ethical Committee of the Hungarian Health Council. All experiments were performed in accordance with applicable guidelines and regulations and informed consent was obtained from the involved patients.

\subsection{Literature Search}

Literature search was performed in the PubMed database (https:/ / pubmed.ncbi.nlm. nih.gov/) using the following search terms: adrenocortical carcinoma; adrenocortical cancer; adrenal cancer; adrenal tumor; and microRNA. Only original articles were selected. Most microRNAs included have been described as differentially expressed by multiple studies. We have selected 16 differentially expressed miRNAs to be included in our study (Table 2). 
Table 2. List of selected, differentially expressed miRNAs based on literature search that were included in our study.

\begin{tabular}{ccc}
\hline miRNAs & Expression in ACC & References \\
\hline$h s a-m i R-7$ & Down-regulated & {$[30,31]$} \\
$h s a-m i R-9$ & Up-regulated & {$[32,33]$} \\
$h s a-m i R-21$ & Up-regulated & {$[34,35]$} \\
$h s a-m i R-195$ & Down-regulated & {$[30,34,36-39]$} \\
$h s a-m i R-205$ & Down-regulated & {$[40,41]$} \\
$h s a-m i R-210$ & Up-regulated & {$[34,39,42,43]$} \\
$h s a-m i R-214$ & Down-regulated & {$[38,42,44]$} \\
$h s a-m i R-335$ & Down-regulated & {$[36,38,45]$} \\
$h s a-m i R-375$ & Down-regulated & {$[42]$} \\
$h s a-m i R-431$ & Down-regulated & {$[44,46]$} \\
$h s a-m i R-483-3 p$ & Up-regulated & {$[34,38,47,48]$} \\
$h s a-m i R-483-5 p$ & Up-regulated & {$[30,34,36,38,39,49-51]$} \\
$h s a-m i R-497$ & Down-regulated & {$[34,38]$} \\
$h s a-m i R-503$ & Up-regulated & {$[36,44,52]$} \\
$h s a-m i R-508$ & Up-regulated & {$[42,44,53]$} \\
$h s a-m i R-511$ & Down-regulated &
\end{tabular}

This list includes miRNAs that are extensively described in the literature to be important in adrenocortical tumor pathogenesis or differential diagnosis (such as hsa-miR-195 or hsa-miR-483-5p, or hsa-miR-503) [30,34,36-39,42,49-51], and also miRNAs where there is only limited evidence of pathogenic relevance. By including more miRNAs to be tested by artificial intelligence, we aimed to increase the chance of finding well-performing miRNA combinations.

\subsection{Sample Processing and RNA Isolation}

Total RNA was isolated by RecoverAll Total Nucleic Acid Isolation Kit for FFPE (catalog number: AM1975, Thermo Fisher Scientific, Waltham, MA, USA). As a spike-in control for isolation efficiency we used $1 \mu \mathrm{L}$ of $0.002 \mathrm{fmol} / \mu \mathrm{L}$ syn-cel-miR-39-3p according to the manufacturer's protocol for miRCURY LNA RNA Spike-in kit (Qiagen GmbH, Hilden, Germany, catalog number: 339390) and was added before the nucleic acid isolation step. Total RNA quantity was measured by NanoDrop 2000 Spectrophotometer (Thermo Fisher Scientific, Waltham, MA, USA) after isolation and Qubit 4 Fluorometer with Qubit ${ }^{\mathrm{TM}}$ hsRNA Assay Kit (Thermo Fisher Scientific, Waltham, MA, USA) before reverse transcription. Total RNA was stored at $-80^{\circ} \mathrm{C}$ until further processing.

\subsection{Analysis of the miRNA Panel Expression by Real-Time RT-qPCR}

A 2-step process for RT-qPCR was used. Each sample was processed separately for all miRNA targets. Ten nanograms of isolated total RNA was used in individual RT reactions.

First, TaqMan miRNA Reverse Transcription Kit (catalog number: 4366596, Thermo Fisher Scientific, Waltham, MA, USA) and individual TaqMan MiRNA Assay primer mixes (catalog number: 4427975, Thermo Fisher Scientific, Waltham, MA, USA) were used to reverse-transcribe total RNA. The expression of hsa-miR-7 (ID: 000386), hsa-miR-9 (ID: 000583), hsa-miR-21 (ID: 000397), hsa-miR-195 (ID: 000494), hsa-miR-205 (ID: 000509), hsa$m i R-210$ (ID: 000512), hsa-miR-214 (ID: 002306), hsa-miR-335 (ID: 000546), hsa-miR-375 (ID: 000564), hsa-miR-431 (ID: 001979), hsa-miR-483-3p (ID: 002339), hsa-miR-483-5p (ID: 002338), hsa-miR-497 (ID: 001043), hsa-miR-503 (ID: 001048), hsa-miR-508 (ID: 001052), and hsa-miR511 (ID: 001111) were measured, and as an internal control RNU48 (ID: 001006) along with cel-miR-39 (ID: 000200) as an external control were used.

For quantification, TaqMan Fast Advanced Master Mix (catalog number: 4444963, Thermo Fisher Scientific, Waltham, MA, USA), with the matching probe mixes on a Quantstudio 7 Flex Real-Time PCR System (Thermo Fisher Scientific, Waltham, MA, USA) according to the manufacturer's protocol, was used. Negative control reactions contained 
no cDNA templates, and all samples were measured in triplicate. We used 0,67 $\mu \mathrm{L}$ of undiluted cDNA as template.

After analysis of the miRNA panel expression by real-time RT-qPCR on the discovery cohort, we proceeded to validate our best performing combinations by carrying out another set of real-time RT-qPCR measurements on an independent validation cohort, but with a further refined group of miRNAs: $h s a-m i R-9$ (ID: 000583), hsa-miR-195 (ID: 000494), hsa-miR210 (ID: 000512), hsa-miR-375 (ID: 000564), hsa-miR-483-3p (ID: 002339), hsa-miR-483-5p (ID: 002338), hsa-miR-497 (ID: 001043), hsa-miR-503 (ID: 001048), and $h s a-m i R-508$ (ID: 001052).

\subsection{Statistical Analysis}

Statistical analysis was carried out with $\mathrm{R}$ for Windows version 4.1.1 (R Foundation for Statistical Computing, 2021, Vienna, Austria). Normalization of miRNAs was performed with the $\Delta \mathrm{Ct}$ method, in which geometric means of intrinsic "housekeeping gene" (RNU48) and extrinsic spike-in (cel-miR-39) served as controls (R package NormqPCR). Down-regulated miRNAs, when presented with no measurable $\mathrm{C} t$ values, were omitted. The order of miRNAs that played prominent role in the group classification of the samples was determined by the random forest method, using the importance measure 'mean decrease in accuracy' ( $\mathrm{R}$ package randomForest), which was used to strengthen relationships already known from the literature [54]. The possibility of automatic classification of samples into ACA or ACC groups was tested by machine learning methods ( $R$ packages nnet and caret) [55,56]. The classification efficiency of possible miRNA combinations was examined by neural network-based, 90-10\% random learner-tester cross validation consisting of 10-10-10 known ACC, ACA, and NAC samples. A hidden-layer neural network-based statistical model was created that randomly selected 9-9-9 samples per group from 10-10-10 histological specimens (learner data set). Classification efficacy of the model was tested on the remaining 1-1-1 samples (tester data set). By repeating this step 1000 times, we were able to determine the miRNA combinations, which had high specificity and sensitivity for group classification. The analysis was also performed both on all 30 samples from all three groups and on the 20 samples from benign and malignant adrenal tumors alone as well. Twenty-four models with at least $90 \%$ classification capability were selected for validation of subsequent machine learning-based classification (Table 3).

During validation, the same ACA and ACC samples were used as previously, and the 43 unknown samples were classified individually, with 10,000 iterations each. The final estimated group classification of the sample was determined by selecting the most common value ( $>50 \%$ ) from the 10,000 estimates.

Sensitivity and specificity for each model were determined-after revealing the benign or malignant histological diagnosis of each sample-by comparing the estimated and the actual groupings from the models. At this point, as a technical step, the ACA group was designated as the "control" group and the ACC group as the "patient" group. Based on the differences between the two classifications, we determined the number of correct results (true positives and negatives), false positive (benign tumor instead of malignant tumor) and false negative (malignant tumor instead of benign tumor) results.

The percentage of correct classifications in the ACA group and the correct classification were compared and plotted by ROC analysis ( $R$ package pROC) [57]. Additional epidemiological measures (e.g., area under curve) were determined using the true group classifications and the percentages of the estimated classification in the ROC analysis. 
Table 3. The 24 miRNA combination models used in the validation cohort.

\begin{tabular}{cc}
\hline Model Number & miRNA Combination \\
\hline 1 & $h s a-m i R-9+h s a-m i R-375$ \\
2 & $h s a-m i R-9+h s a-m i R-503$ \\
3 & $h s a-m i R-375+h s a-m i R-503$ \\
4 & $h s a-m i R-210+h s a-m i R-503$ \\
5 & $h s a-m i R-375+h s a-m i R-497$ \\
6 & $h s a-m i R-483-3 p+h s a-m i R-503$ \\
7 & $h s a-m i R-503+h s a-m i R-508$ \\
8 & $h s a-m i R-195+h s a-m i R-503+h s a-m i R-508$ \\
9 & $h s a-m i R-195+h s a-m i R-210+h s a-m i R-503$ \\
10 & $h s a-m i R-9+h s a-m i R-195+h s a-m i R-503$ \\
11 & $h s a-m i R-9+h s a-m i R-210+h s a-m i R-503$ \\
12 & $h s a-m i R-9+h s a-m i R-375+h s a-m i R-503$ \\
13 & $h s a-m i R-9+h s a-m i R-483-3 p+h s a-m i R-503$ \\
14 & $h s a-m i R-9+h s a-m i R-497+h s a-m i R-503$ \\
15 & $h s a-m i R-195+h s a-m i R-375+h s a-m i R-497$ \\
16 & $h s a-m i R-210+h s a-m i R-375+h s a-m i R-503$ \\
17 & $h s a-m i R-210+h s a-m i R-483-5 p+h s a-m i R-503$ \\
18 & $h s a-m i R-375+h s a-m i R-503+h s a-m i R-508$ \\
19 & $h s a-m i R-375+h s a-m i R-483-3 p+h s a-m i R-503$ \\
20 & $h s a-m i R-9+h s a-m i R-195+h s a-m i R-375+h s a-m i R-503$ \\
21 & $h s a-m i R-9+h s a-m i R-210+h s a-m i R-483-5 p+h s a-m i R-503$ \\
22 & $h s a-m i R-210+h s a-m i R-375+h s a-m i R-503+h s a-m i R-508$ \\
23 & $h s a-m i R-375+h s a-m i R-483-5 p+h s a-m i R-503+h s a-m i R-508$ \\
24 & $h s a-m i R-375+h s a-m i R-497+h s a-m i R-503+h s a-m i R-508$ \\
\hline & \\
& \\
&
\end{tabular}

\section{Results}

\section{1. miRNA Expression in the Discovery Cohort by RT-qPCR}

RT-qPCR was performed on 10-10-10 known ACA, ACC, NAC FFPE tissue samples in the discovery cohort. The list of selected miRNAs is presented in Table 2. Random forest results revealed that hsa-miR-503, hsa-miR-483_3p, hsa-miR-195, hsa-miR-375 and hsa-miR-483_5p were the top 5 miRNAs to properly group the 30 samples into their respective groups. (Figure 1 presents box plots representing the expression of these five miRNA in ACA and ACC.) The best performing miRNA combinations (statistical models) were selected by neural network-based, $90-10 \%$ random learner-tester cross validation. Twenty-four statistical models (Table 3 ) with at least $90 \%$ grouping capability were selected for validation. These 24 models contain the following miRNAs: hsa-miR-9, hsa-miR195, hsa-miR-210, hsa-miR-375, hsa-miR-483-3p, hsa-miR-483-5p, hsa-miR-497, hsa-miR-503, and $h s a-m i R-508$.

\subsection{Diagnostic Performance of the miRNA Models by RT-qPCR}

In total, 43 independent FFPE samples (22 ACA and 21 ACC) were measured in the validation cohort by RT-qPCR to establish the utility of selected miRNA combinations as markers of malignancy. Table 4 presents the sensitivity, specificity, area under curve, positive and negative predictive values of the 24 models. Among these, 3 models yielded sensitivity and specificity both over $90 \%$ : model 9 (hsa-miR-195 + hsa-miR$210+$ hsa-miR-503), model 16 (hsa-miR-210 + hsa-miR-375 + hsa-miR-503) and model 17 (hsa-miR-210 + hsa-miR-483-5p + hsa-miR-503) (Figure 2). False negative (V14, V19) and false positive (V33) samples are marked in Table S1. These samples were commonly missed by the three best performing models, whereas Sample V38 has been recognized by Model 17 , and not by the two other models. We could not find common or peculiar features in the falsely classified samples. The values for individual miRNAs are presented in Table 5. These combination-based predictions are clearly superior to the diagnostic performance of individual miRNAs. 

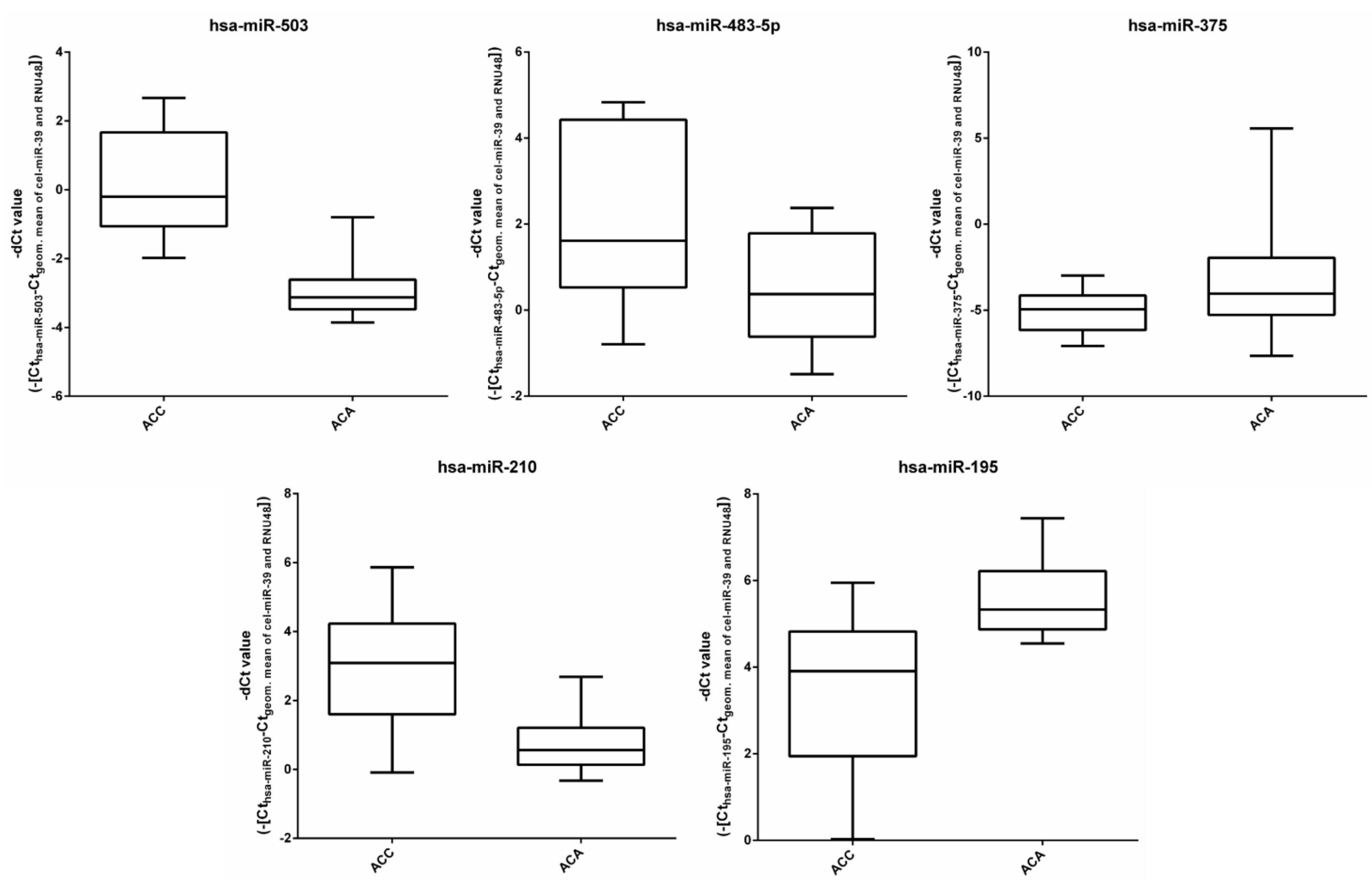

Figure 1. Box plots representing the expression of the top five miRNAs relative to the geometric means of cel-miR-39 and RNU48 in ACA and ACC samples. The top 5 selected miRNAs contributing to the best performing three models were determined based on artificial intelligence.

Table 4. Diagnostic performance of the 24 miRNA combination models. The best performing three models are highlighted in bold.

\begin{tabular}{cccccc}
\hline $\begin{array}{c}\text { Model } \\
\text { Number }\end{array}$ & Sensitivity & Specificity & $\begin{array}{c}\text { Area under } \\
\text { Curve (AUC) }\end{array}$ & $\begin{array}{c}\text { Negative } \\
\text { Predictive Value }\end{array}$ & $\begin{array}{c}\text { Positive } \\
\text { Predictive Value }\end{array}$ \\
\hline 1 & $72.73 \%$ & $42.86 \%$ & $56.49 \%$ & $57.14 \%$ & $60.00 \%$ \\
2 & $72.73 \%$ & $85.71 \%$ & $81.17 \%$ & $84.21 \%$ & $75.00 \%$ \\
3 & $90.91 \%$ & $85.71 \%$ & $90.04 \%$ & $86.96 \%$ & $90.00 \%$ \\
4 & $86.36 \%$ & $90.48 \%$ & $88.42 \%$ & $90.48 \%$ & $86.36 \%$ \\
5 & $86.36 \%$ & $66.67 \%$ & $76.52 \%$ & $73.08 \%$ & $82.35 \%$ \\
6 & $72.73 \%$ & $95.24 \%$ & $86.15 \%$ & $94.12 \%$ & $76.92 \%$ \\
7 & $81.82 \%$ & $90.48 \%$ & $85.93 \%$ & $90.00 \%$ & $82.61 \%$ \\
8 & $86.36 \%$ & $85.71 \%$ & $87.34 \%$ & $86.36 \%$ & $85.71 \%$ \\
9 & $90.91 \%$ & $\mathbf{9 0 . 4 8 \%}$ & $\mathbf{9 0 . 6 9 \%}$ & $\mathbf{9 0 . 9 1 \%}$ & $\mathbf{9 0 . 4 8 \%}$ \\
10 & $68.18 \%$ & $85.71 \%$ & $78.90 \%$ & $83.33 \%$ & $72.00 \%$ \\
11 & $86.36 \%$ & $85.71 \%$ & $88.10 \%$ & $86.36 \%$ & $85.71 \%$ \\
12 & $86.36 \%$ & $80.95 \%$ & $83.66 \%$ & $82.61 \%$ & $85.00 \%$ \\
13 & $68.18 \%$ & $90.48 \%$ & $82.47 \%$ & $88.24 \%$ & $73.08 \%$ \\
14 & $77.27 \%$ & $85.71 \%$ & $80.84 \%$ & $85.00 \%$ & $78.26 \%$ \\
15 & $86.36 \%$ & $66.67 \%$ & $76.52 \%$ & $73.08 \%$ & $82.35 \%$ \\
16 & $\mathbf{9 0 . 9 1 \%}$ & $\mathbf{9 0 . 4 8 \%}$ & $\mathbf{9 0 . 6 9 \%}$ & $\mathbf{9 0 . 9 1 \%}$ & $\mathbf{9 0 . 4 8 \%}$ \\
17 & $\mathbf{9 0 . 9 1 \%}$ & $\mathbf{9 5 . 2 4 \%}$ & $\mathbf{9 2 . 8 6 \%}$ & $\mathbf{9 5 . 2 4 \%}$ & $\mathbf{9 0 . 9 1 \%}$ \\
18 & $90.91 \%$ & $85.71 \%$ & $90.04 \%$ & $86.96 \%$ & $90.00 \%$ \\
19 & $77.27 \%$ & $90.48 \%$ & $85.61 \%$ & $89.47 \%$ & $79.17 \%$ \\
20 & $86.36 \%$ & $80.95 \%$ & $85.50 \%$ & $82.61 \%$ & $85.00 \%$ \\
21 & $86.36 \%$ & $80.95 \%$ & $85.71 \%$ & $82.61 \%$ & $85.00 \%$ \\
22 & $90.91 \%$ & $85.71 \%$ & $90.04 \%$ & $86.96 \%$ & $90.00 \%$ \\
23 & $90.91 \%$ & $85.71 \%$ & $88.31 \%$ & $86.96 \%$ & $90.00 \%$ \\
24 & $90.91 \%$ & $85.71 \%$ & $89.39 \%$ & $86.96 \%$ & $90.00 \%$ \\
\hline
\end{tabular}




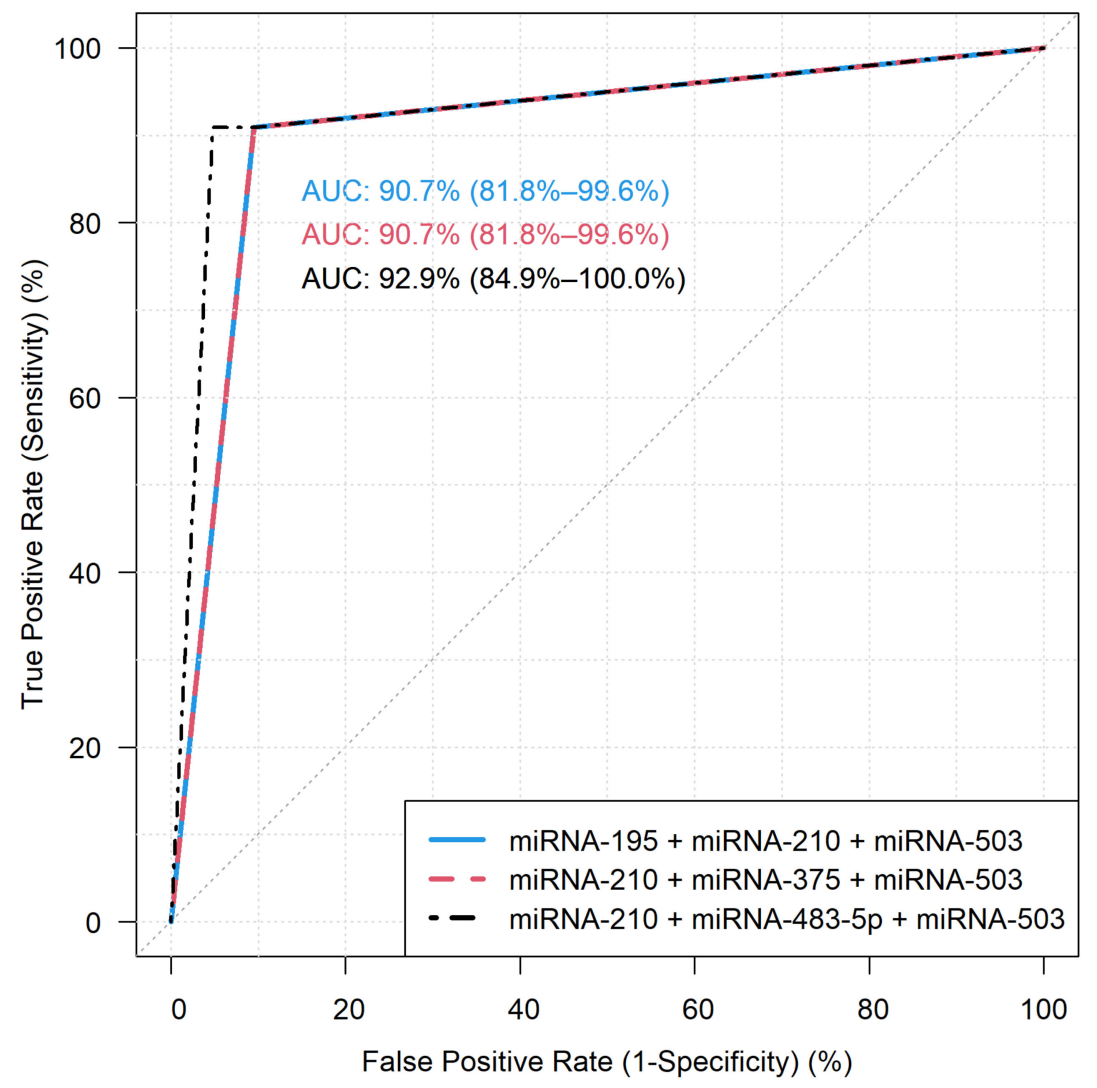

Figure 2. ROC curves of the best performing three miRNA combinations. Model 9: hsa-miR-195 + hsa-miR-210 + hsa-miR-503 (left upper corner), model 16: hsa-miR-210 + hsa-miR-375 + hsa-miR-503 (right upper corner), model 17: $h s a-m i R-210+h s a-m i R-483-5 p+h s a-m i R-503$ (down). AUC: area under curve.

Table 5. Individual diagnostic performance of the miRNAs included in the 24 miRNA combination models.

\begin{tabular}{cccccc}
\hline miRNA & Sensitivity & Specificity & $\begin{array}{c}\text { Area under } \\
\text { Curve (AUC) }\end{array}$ & $\begin{array}{c}\text { Negative } \\
\text { Predictive } \\
\text { Value }\end{array}$ & $\begin{array}{c}\text { Positive } \\
\text { Predictive } \\
\text { Value }\end{array}$ \\
\hline hsa-miR-9 & $54.55 \%$ & $61.90 \%$ & $59.52 \%$ & $60.00 \%$ & $56.52 \%$ \\
$h s a-m i R-195$ & $86.36 \%$ & $71.43 \%$ & $78.90 \%$ & $76.00 \%$ & $83.33 \%$ \\
$h s a-m i R-210$ & $68.18 \%$ & $80.95 \%$ & $76.41 \%$ & $78.95 \%$ & $70.83 \%$ \\
$h s a-m i R-375$ & $81.82 \%$ & $23.81 \%$ & $53.68 \%$ & $52.94 \%$ & $55.56 \%$ \\
$h s a-m i R-483-3 p$ & $54.55 \%$ & $90.48 \%$ & $74.57 \%$ & $85.71 \%$ & $65.52 \%$ \\
$h s a-m i R-483-5 p$ & $81.82 \%$ & $90.48 \%$ & $86.15 \%$ & $90.00 \%$ & $82.61 \%$ \\
$h s a-m i R-497$ & $86.36 \%$ & $80.95 \%$ & $83.66 \%$ & $82.61 \%$ & $85.00 \%$ \\
$h s a-m i R-503$ & $81.82 \%$ & $90.48 \%$ & $86.15 \%$ & $90.00 \%$ & $82.61 \%$ \\
$h s a-m i R-508$ & $59.09 \%$ & $52.38 \%$ & $58.33 \%$ & $56.52 \%$ & $55.00 \%$ \\
\hline
\end{tabular}

\section{Discussion}

The histological diagnosis of adrenocortical tumors is challenging. In this study, we assessed the applicability for various miRNA combinations established by an artificial intelligence approach (machine learning and neural networks) that could reliably be utilized as markers of adrenocortical malignancy.

Sixteen miRNAs were included in our study, based on the literature search, but the established miRNA combinations include only 5 of these (hsa-miR-195, hsa-miR-210, hsa$m i R-375, h s a-m i R-483-5 p$, and $h s a-m i R-503)$. Not surprisingly, this 5-miRNA set includes the miRNAs that have been described in most adrenocortical tumor studies as differentially expressed between benign and malignant tumors. 
Hsa-miR-195 was shown to be underexpressed in ACC compared to ACA in various studies [30,34,36-39]. Furthermore, the underexpression of hsa-miR-195 was associated with poor outcome, and lower circulating levels of $h s a-m i R-195$ tended to be correlated with a larger tumor size $[30,36,38]$. On the other hand, the up-regulation of $h s a-m i R-195$ decreased cell proliferation in human NCI-H295R ACC cells [34]. The gene for hsa-miR-195 is located within the genomic region of $17 \mathrm{p} 13$, that was shown to be frequently lost in adrenocortical tumors [58].

$H s a-m i R-210$ is a general hypoxamiR as it was shown to be involved in tumor hypoxia, thereby, the overexpression of $h s a-m i R-210$ seems to be a common event in various tumors [59]. Hsa-miR-210 is regulated by the hypoxia-inducible factor $1 \alpha(\mathrm{HIF} 1 \alpha)$, an important factor in antitumoral therapy resistance [60-62]. It was shown to be overexpressed in ACC compared to ACA and NAC in multiple studies [34,39,42,43], and also significantly overexpressed in ACC with distant metastases [38]. High expression of hsa-miR-210 was associated with poor prognosis [47].

Hsa-miR-375 was shown to be significantly underexpressed in ACC and ACA compared to NAC in our previous study [42]. It targets certain oncogenes, such as $A E G-$ 1/MTDH, PDK1, YWHAZ/14-3-3ろ, YAP and JAK2, in multiple types of carcinomas [63-67]. Reciprocal action between Wnt- $\beta$-catenin signaling and $h s a-m i R-375$ has been proposed [68]. The Wnt- $\beta$-catenin pathway is an important factor in the pathogenesis of ACC [69,70]. It was surprising that this miRNA has been included in the models by artificial intelligence, and even in one of the best performing combinations (Model 16).

Overexpressed $h s a-m i R-483-5 p$ is considered to be the best marker of adrenocortical malignancy $[26,31,33,35,36,41,47-49,69,70]$. However, we have recently shown its limitation in the differentiation of ACC and adrenal myelolipoma [71]. Hsa-miR-483-5p is coexpressed with the insulin-like growth factor 2 (IGF2) from the same locus at 11p15.5 [37]. Overexpression of IGF2 mRNA is a main feature of ACC [72,73]. N-myc downstream-regulated gene family members 2 and 4 (NDRG2 and NDRG4) were identified as targets of $m i R-483-5 p$, and their expression was inversely correlated with $m i R-483-5 p$ [74]. Hsa-miR-483-5p is also an interesting example of miRNA's tissue and disease specificity as it has been shown to be down-regulated in Wilms tumors and glioma cells, suggesting its tumor suppressor activity in these tumors and tissues [75,76].

Hsa-miR-503 has also been described in several adrenal tumor studies [34,36,38,42,43]. Its pathogenic role was also proposed in other malignancies $[77,78]$. A larger tumor size has been shown to correlate with the overexpression of $h s a-m i R-503$, and also, a significant correlation with Weiss-criteria, clinical outcome and survival was revealed [34,38]. HsamiR-503 has previously been described as a direct cell cycle and differentiation regulator in different cell lines $[79,80]$.

The three best-performing miRNA combinations yielded clearly superior sensitivity and specificity values than the individual miRNAs included in the combinations (Table 4 vs. Table 5.) and also than the previous literature data for individual miRNAs (e.g., sensitivityspecificity: 68.7-93.7; 73.7-100 for $h s a-m i R-195$ and for $h s a-m i R-483-5 p$, respectively [33]). Some literature data, however, show comparable, or even better diagnostic performance data than our combinations. For example, in our previous study, the combination of $h s a-$ $m i R-511$ and $h s a-m i R-503$ was associated with 100\% sensitivity and $97 \%$ specificity [42], and in Feinmesser's study a 100\% sensitivity and $96 \%$ specificity of the $h s a-m i R-497$ and $h s a-m i R-$ $34 a$ combination was noted [38]. In most previous studies, however, smaller cohorts were included, (e.g., only 7 and 17 ACC samples included in the two above mentioned studies, respectively $[38,42])$. Different cohort compositions, platforms and statistical methods might also be accounted for these differences.

Our study certainly has limitations. These include the limited set of miRNAs examined and the sizes of the cohorts that are larger than in most previous studies but should still be augmented to assess the clinical utility of the markers identified. Moreover, we performed our measurements on FFPE samples in a retrospective setup, hence the clinical utility 
of these miRNA combinations should further be examined on fresh frozen samples in a prospective manner.

Using small sample sizes in machine learning techniques can lead to biased machine learning performance estimates. To overcome this type of bias, it is recommended to use a different, new dataset for validation. In our study, both the baseline and validation cohorts consist of different patients; therefore, our results do not suffer from this type of bias.

Another type of bias can be introduced from using specific types of cross validation. It was previously reported that using nested types of cross-validation produce unbiased and robust results [81]. The $90 \%-10 \%$ random learner-tester cross-validation used in our study belongs to the nested cross-validation family.

The sensitivity and specificity values of the three best performing biomarker combinations appear to be promising for clinical introduction. Besides a useful adjunct to histological analysis of surgically resected tumor specimens, the possible testing of these microRNA panels on adrenal biopsy samples might also be envisaged. Adrenal biopsy is currently not recommended in the work-up of adrenal tumors, only in exceptional cases, mainly due to the difficulties of histological analysis, but there are also some possible complications $[3,5,11,12]$. If the diagnosis of malignancy could be reliably established by using these microRNA panels from small biopsy samples, this might even broaden the use of adrenal biopsy in preoperative diagnosis and the current recommendations might be revisited.

\section{Conclusions}

In this study, novel miRNA marker combinations have been established by artificial intelligence-based methods showing high sensitivity and specificity that could aid in the differential diagnosis of benign and malignant adrenocortical tissue specimens. The clinical utility of these biomarkers should be further validated in even larger sample cohorts, and their potential use on biopsy samples might also be evaluated. Prospective analysis on fresh frozen samples is also warranted. These miRNA combinations could help postoperative histological diagnosis.

\section{Patents}

Claims for patenting the three best performing biomarker combinations have been submitted to the Hungarian Intellectual Property Office (P2200007).

Supplementary Materials: The following supporting information can be downloaded at: https: / / www.mdpi.com/article/10.3390/cancers14040895/s1, Table S1: Clinical and main pathological characteristics of the tumor samples

Author Contributions: Conceptualization: P.I.; methodology: P.I.T., Z.H., G.N.; biostatistics: Z.H.; validation: P.I.T., G.N.; clinical management of patients; P.I., N.S., J.T., M.T.; pathology/histology: K.B., T.M.; writing—original draft preparation: P.I.T.; writing—review and editing: P.I.T., P.I., A.P.; supervision, P.I.; funding acquisition, P.I. All authors have read and agreed to the published version of the manuscript.

Funding: This research was funded by Hungarian National Research, Development and Innovation Office (NKFIH) grant K134215 to Dr. Peter Igaz. The study was also financed by the Higher Education Institutional Excellence Program - of the Ministry of Human Capacities in Hungary, within the framework of the molecular biology thematic program of the Semmelweis University and by the ÚNKP-21-3 New National Excellence Program of the Ministry of Human Capacities.

Institutional Review Board Statement: The study was conducted according to the guidelines of the Declaration of Helsinki and approved by the Ethical Board of the Hungarian Health Science Council (ETT-TUKEB) (24441-2/2016/EKU).

Informed Consent Statement: Informed consent was obtained from all subjects involved in the study. 
Data Availability Statement: Data are contained within the article or supplementary material. The data presented in this study are available in Table S1.

Conflicts of Interest: The authors declare no conflict of interest. The funders had no role in the design of the study; in the collection, analyses, or interpretation of data; in the writing of the manuscript, or in the decision to publish the results.

\section{References}

1. Bovio, S.; Cataldi, A.; Reimondo, G.; Sperone, P.; Novello, S.; Berruti, A.; Borasio, P.; Fava, C.; Dogliotti, L.; Scagliotti, G.V.; et al. Prevalence of adrenal incidentaloma in a contemporary computerized tomography series. J. Endocrinol. Investig. 2006, 29, 298-302. [CrossRef]

2. $\quad$ Libé, R.; Borget, I.; Ronchi, C.L.; Zaggia, B.; Kroiss, M.; Kerkhofs, T.; Bertherat, J.; Volante, M.; Quinkler, M.; Chabre, O.; et al. Prognostic factors in stage III-IV adrenocortical carcinomas (ACC): An European Network for the Study of Adrenal Tumor (ENSAT) study. Ann. Oncol. 2015, 26, 2119-2125. [CrossRef] [PubMed]

3. Fassnacht, M.; Dekkers, O.M.; Else, T.; Baudin, E.; Berruti, A.; De Krijger, R.R.; Haak, H.R.; Mihai, R.; Assie, G.; Terzolo, M European Society of Endocrinology Clinical Practice Guidelines on the management of adrenocortical carcinoma in adults, in collaboration with the European Network for the Study of Adrenal Tumors. Eur. J. Endocrinol. 2018, 179, G1-G46. [CrossRef] [PubMed]

4. Terzolo, M.; Daffara, F.; Ardito, A.; Zaggia, B.; Basile, V.; Ferrari, L.; Berruti, A. Management of adrenal cancer: A 2013 update. J. Endocrinol. Investig. 2014, 37, 207-217. [CrossRef] [PubMed]

5. $\quad$ Fassnacht, M.; Arlt, W.; Bancos, I.; Dralle, H.; Newell-Price, J.; Sahdev, A.; Tabarin, A.; Terzolo, M.; Tsagarakis, S.; Dekkers, O.M. Management of adrenal incidentalomas: European Society of Endocrinology Clinical Practice Guideline in collaboration with the European Network for the Study of Adrenal Tumors. Eur. J. Endocrinol. 2016, 175, G1-G34. [CrossRef]

6. Lattin, G.E.; Sturgill, E.D.; Tujo, C.A.; Marko, J.; Sanchez-Maldonado, K.W.; Craig, W.D.; Lack, E.E. From the radiologic pathology archives: Adrenal tumors and tumor-like conditions in the adult: Radiologic-pathologic correlation. Radiographics 2014, 34, 805-829. [CrossRef]

7. Bancos, I.; Arlt, W. Diagnosis of a malignant adrenal mass: The role of urinary steroid metabolite profiling. Curr. Opin. Endocrinol. Diabetes Obes. 2017, 24, 200-207. [CrossRef]

8. Viëtor, C.L.; Creemers, S.G.; van Kemenade, F.J.; van Ginhoven, T.M.; Hofland, L.J.; Feelders, R.A. How to Differentiate Benign from Malignant Adrenocortical Tumors? Cancers 2021, 13, 4383. [CrossRef]

9. Mazzaglia, P.J.; Monchik, J.M. Limited Value of Adrenal Biopsy in the Evaluation of Adrenal Neoplasm: A Decade of Experience. Arch. Surg. 2009, 144, 465-470. [CrossRef]

10. Williams, A.R.; Hammer, G.D.; Else, T. Transcutaneous Biopsy of Adrenocortical Carcinoma is rarely helpful in diagnosis, potentially harmful, but does not affect patient outcome. Eur. J. Endocrinol. 2014, 170, 829. [CrossRef]

11. Zhang, C.D.; Delivanis, D.A.; Eiken, P.W.; Atwell, T.D.; Bancos, I. Adrenal biopsy: Performance and use. Minerva Endocrinol. 2019, 44, 288-300. [CrossRef]

12. Bancos, I.; Tamhane, S.; Shah, M.; Delivanis, D.A.; Alahdab, F.; Arlt, W.; Fassnacht, M.; Murad, M.H. DIAGNOSIS OF ENDOCRINE DISEASE: The diagnostic performance of adrenal biopsy: A systematic review and meta-analysis. Eur. J. Endocrinol. 2016, 175, R65-R80. [CrossRef]

13. Condrat, C.E.; Thompson, D.C.; Barbu, M.G.; Bugnar, O.L.; Boboc, A.; Cretoiu, D.; Suciu, N.; Cretoiu, S.M.; Voinea, S.C. miRNAs as Biomarkers in Disease: Latest Findings Regarding Their Role in Diagnosis and Prognosis. Cells 2020, 9, 276. [CrossRef]

14. Gebert, L.F.R.; MacRae, I.J. Regulation of microRNA function in animals. Nat. Rev. Mol. Cell Biol. 2018, 20, 21-37. [CrossRef]

15. Krol, J.; Loedige, I.; Filipowicz, W. The widespread regulation of microRNA biogenesis, function and decay. Nat. Rev. Genet. 2010, 11, 597-610. [CrossRef]

16. Ritland Politz, J.C.; Hogan, E.M.; Pederson, T. MicroRNAs with a nucleolar location. RNA 2009, 15, 1705. [CrossRef]

17. O'Brien, J.; Hayder, H.; Zayed, Y.; Peng, C. Overview of microRNA biogenesis, mechanisms of actions, and circulation. Front. Endocrinol. 2018, 9, 402. [CrossRef]

18. Peng, Y.; Croce, C.M. The role of MicroRNAs in human cancer. Signal Transduct. Target. Ther. 2016, 1, 1-9. [CrossRef]

19. Hayes, J.; Peruzzi, P.P.; Lawler, S. MicroRNAs in cancer: Biomarkers, functions and therapy. Trends Mol. Med. 2014, 20, 460-469. [CrossRef]

20. Igaz, I.; Igaz, P. Tumor surveillance by circulating microRNAs: A hypothesis. Cell. Mol. Life Sci. 2014, 71, 4081-4087. [CrossRef]

21. Ma, Y.; She, X.; Ming, Y.Z.; Wan, Q. quan miR-24 promotes the proliferation and invasion of HCC cells by targeting SOX7. Tumor Biol. 2014, 35, 10731-10736. [CrossRef]

22. Yin, Y.; Zhong, J.; Li, S.W.; Li, J.Z.; Zhou, M.; Chen, Y.; Sang, Y.; Liu, L. TRIM11, a direct target of miR-24-3p, promotes cell proliferation and inhibits apoptosis in colon cancer. Oncotarget 2016, 7, 86755. [CrossRef]

23. Weber, J.A.; Baxter, D.H.; Zhang, S.; Huang, D.Y.; Huang, K.H.; Lee, M.J.; Galas, D.J.; Wang, K. The MicroRNA Spectrum in 12 Body Fluids. Clin. Chem. 2010, 56, 1733-1741. [CrossRef] 
24. Hall, J.S.; Taylor, J.; Valentine, H.R.; Irlam, J.J.; Eustace, A.; Hoskin, P.J.; Miller, C.J.; West, C.M.L. Enhanced stability of microRNA expression facilitates classification of FFPE tumour samples exhibiting near total mRNA degradation. Br. J. Cancer 2012, 107, 684-694. [CrossRef]

25. Kozomara, A.; Birgaoanu, M.; Griffiths-Jones, S. miRBase: From microRNA sequences to function. Nucleic Acids Res. 2019, 47, D155. [CrossRef]

26. Igaz, P.; Igaz, I.; Nagy, Z.; Nyíro, G.; Szabó, P.M.; Falus, A.; Patócs, A.; Rácz, K. MicroRNAs in adrenal tumors: Relevance for pathogenesis, diagnosis, and therapy. Cell. Mol. Life Sci. 2014, 72, 417-428. [CrossRef]

27. Decmann, A.; Perge, P.; Turai, P.I.; Patócs, A.; Igaz, P. Non-Coding RNAs in Adrenocortical Cancer: From Pathogenesis to Diagnosis. Cancers 2020, 12, 461. [CrossRef]

28. Chehade, M.; Bullock, M.; Glover, A.; Hutvagner, G.; Sidhu, S. Key MicroRNA's and Their Targetome in Adrenocortical Cancer. Cancers 2020, 12, 2198. [CrossRef]

29. Singh, P.; Soon, P.S.H.; Feige, J.J.; Chabre, O.; Zhao, J.T.; Cherradi, N.; Lalli, E.; Sidhu, S.B. Dysregulation of microRNAs in adrenocortical tumors. Mol. Cell. Endocrinol. 2012, 351, 118-128. [CrossRef]

30. Soon, P.S.H.; Tacon, L.J.; Gill, A.J.; Bambach, C.P.; Sywak, M.S.; Campbell, P.R.; Yeh, M.W.; Wong, S.G.; Clifton-Bligh, R.J.; Robinson, B.G.; et al. miR-195 and miR-483-5p Identified as Predictors of Poor Prognosis in Adrenocortical Cancer. Clin. Cancer Res. 2009, 15, 7684-7692. [CrossRef]

31. Glover, A.R.; Zhao, J.T.; Gill, A.J.; Weiss, J.; Mugridge, N.; Kim, E.; Feeney, A.L.; Ip, J.C.; Reid, G.; Clarke, S.; et al. microRNA-7 as a tumor suppressor and novel therapeutic for adrenocortical carcinoma. Oncotarget 2015, 6, 36675. [CrossRef] [PubMed]

32. Faria, A.M.; Sbiera, S.; Ribeiro, T.C.; Soares, I.C.; Mariani, B.M.P.; Freire, D.S.; De Sousa, G.R.V.; Lerario, A.M.; Ronchi, C.L.; Deutschbein, T.; et al. Expression of LIN28 and its regulatory microRNAs in adult adrenocortical cancer. Clin. Endocrinol. 2015, 82, 481-488. [CrossRef] [PubMed]

33. Khafaei, M.; Rezaie, E.; Mohammadi, A.; Shahnazi Gerdehsang, P.; Ghavidel, S.; Kadkhoda, S.; Zorrieh Zahra, A.; Forouzanfar, N.; Arabameri, H.; Tavallaie, M. miR-9: From function to therapeutic potential in cancer. J. Cell. Physiol. 2019, 234, 14651-14665. [CrossRef] [PubMed]

34. Özata, D.M.; Caramuta, S.; Velázquez-Fernández, D.; Akçakaya, P.; Xie, H.; Höög, A.; Zedenius, J.; Bäckdahl, M.; Larsson, C.; Lui, W.O. The role of microRNA deregulation in the pathogenesis of adrenocortical carcinoma. Endocr. Relat. Cancer 2011, 18, 643-655. [CrossRef]

35. Romero, D.G.; Plonczynski, M.W.; Carvajal, C.A.; Gomez-Sanchez, E.P.; Gomez-Sanchez, C.E. Microribonucleic Acid-21 Increases Aldosterone Secretion and Proliferation in H295R Human Adrenocortical Cells. Endocrinology 2008, 149, 2477. [CrossRef]

36. Chabre, O.; Libé, R.; Assie, G.; Barreau, O.; Bertherat, J.; Bertagna, X.; Feige, J.J.; Cherradi, N. Serum miR-483-5p and miR-195 are predictive of recurrence risk in adrenocortical cancer patients. Endocr. Relat. Cancer 2013, 20, 579-594. [CrossRef]

37. Patterson, E.E.; Holloway, A.K.; Weng, J.; Fojo, T.; Kebebew, E. MicroRNA profiling of adrenocortical tumors reveals miR-483 as a marker of malignancy. Cancer 2011, 117, 1630. [CrossRef]

38. Feinmesser, M.; Benbassat, C.; Meiri, E.; Benjamin, H.; Lebanony, D.; Lebenthal, Y.; De Vries, L.; Drozd, T.; Spector, Y. Specific microRNAs differentiate adrenocortical adenomas from carcinomas and correlate with weiss histopathologic system. Appl. Immunohistochem. Mol. Morphol. 2015, 23, 522-531. [CrossRef]

39. Szabó, D.R.; Luconi, M.; Szabó, P.M.; Tóth, M.; Szücs, N.; Horányi, J.; Nagy, Z.; Mannelli, M.; Patócs, A.; Rácz, K.; et al. Analysis of circulating microRNAs in adrenocortical tumors. Lab. Investig. 2013, 94, 331-339. [CrossRef]

40. Wu, Y.; Wang, W.; Hu, W.; Xu, W.; Xiao, G.; Nie, Q.; Ouyang, K.; Chen, S. MicroRNA-205 suppresses the growth of adrenocortical carcinoma SW-13 cells via targeting Bcl-2. Oncol. Rep. 2015, 34, 3104-3110. [CrossRef]

41. Pereira, S.S.; Monteiro, M.P.; Antonini, S.R.; Pignatelli, D. Apoptosis regulation in adrenocortical carcinoma. Endocr. Connect. 2019, 8, R91. [CrossRef]

42. Tömböl, Z.; Szabó, P.M.; Molnár, V.; Wiener, Z.; Tölgyesi, G.; Horányi, J.; Riesz, P.; Reismann, P.; Patócs, A.; Likó, I.; et al Integrative molecular bioinformatics study of human adrenocortical tumors: MicroRNA, tissue-specific target prediction, and pathway analysis. Endocr. Relat. Cancer 2009, 16, 895-906. [CrossRef]

43. Koperski, L.; Kotlarek, M.; Swierniak, M.; Kolanowska, M.; Kubiak, A.; Górnicka, B.; Jazdzewski, K.; Wójcicka, A. Next-generation sequencing reveals microRNA markers of adrenocortical tumors malignancy. Oncotarget 2017, 8, 49191. [CrossRef]

44. Assié, G.; Letouzé, E.; Fassnacht, M.; Jouinot, A.; Luscap, W.; Barreau, O.; Omeiri, H.; Rodriguez, S.; Perlemoine, K.; René-Corail, F.; et al. Integrated genomic characterization of adrenocortical carcinoma. Nat. Genet. 2014, 46, 607-612. [CrossRef]

45. Schmitz, K.J.; Helwig, J.; Bertram, S.; Sheu, S.Y.; Suttorp, A.C.; Seggewiß, J.; Willscher, E.; Walz, M.K.; Worm, K.; Schmid, K.W. Differential expression of microRNA-675, microRNA-139-3p and microRNA-335 in benign and malignant adrenocortical tumours. J. Clin. Pathol. 2011, 64, 529-535. [CrossRef]

46. Kwok, G.T.Y.; Zhao, J.T.; Glover, A.R.; Gill, A.J.; Clifton-Bligh, R.; Robinson, B.G.; Ip, J.C.Y.; Sidhu, S.B. microRNA-431 as a Chemosensitizer and Potentiator of Drug Activity in Adrenocortical Carcinoma. Oncologist 2019, 24, e241. [CrossRef]

47. Duregon, E.; Rapa, I.; Votta, A.; Giorcelli, J.; Daffara, F.; Terzolo, M.; Scagliotti, G.V.; Volante, M.; Papotti, M. MicroRNA expression patterns in adrenocortical carcinoma variants and clinical pathologic correlations. Hum. Pathol. 2014, 45, 1555-1562. [CrossRef]

48. Veronese, A.; Lupini, L.; Consiglio, J.; Visone, R.; Ferracin, M.; Fornari, F.; Zanesi, N.; Alder, H.; D’Elia, G.; Gramantieri, L.; et al. Oncogenic Role of miR-483-3p at the IGF2/483 Locus. Cancer Res. 2010, 70, 3140. [CrossRef] 
49. Perge, P.; Butz, H.; Pezzani, R.; Bancos, I.; Nagy, Z.; Pálóczi, K.; Nyíro, G.; Decmann, Á.; Pap, E.; Luconi, M.; et al. Evaluation and diagnostic potential of circulating extracellular vesicle-associated microRNAs in adrenocortical tumors. Sci. Rep. 2017, 7, 5474. [CrossRef]

50. Salvianti, F.; Canu, L.; Poli, G.; Armignacco, R.; Scatena, C.; Cantini, G.; Di Franco, A.; Gelmini, S.; Ercolino, T.; Pazzagli, M.; et al. New insights in the clinical and translational relevance of miR483-5p in adrenocortical cancer. Oncotarget 2017, 8, 65525. [CrossRef]

51. Decmann, A.; Bancos, I.; Khanna, A.; Thomas, M.A.; Turai, P.; Perge, P.; Pintér, J.Z.; Tóth, M.; Patócs, A.; Igaz, P. Comparison of plasma and urinary microRNA-483-5p for the diagnosis of adrenocortical malignancy. J. Biotechnol. 2019, 297, 49-53. [CrossRef]

52. Zheng, S.; Cherniack, A.D.; Dewal, N.; Moffitt, R.A.; Danilova, L.; Murray, B.A.; Lerario, A.M.; Else, T.; Knijnenburg, T.A.; Ciriello, G.; et al. Comprehensive Pan-Genomic Characterization of Adrenocortical Carcinoma. Cancer Cell 2016, 29, 723. [CrossRef]

53. Goh, G.; Scholl, U.I.; Healy, J.M.; Choi, M.; Prasad, M.L.; Nelson-Williams, C.; Kuntsman, J.W.; Korah, R.; Suttorp, A.C.; Dietrich, D.; et al. Recurrent activating mutation in PRKACA in cortisol-producing adrenal tumors. Nat. Genet. 2014, 46, 613. [CrossRef]

54. Liaw, A.; Wiener, M. Classification and Regression by randomForest. $R$ News 2002, 2, 18-22.

55. Modern Applied Statistics with S. Available online: https://link.springer.com/book/10.1007/978-0-387-21706-2 (accessed on 7 December 2021).

56. Caret: Classification and Regression Training R Package Version 6.0-90. Available online: https:/ CRAN.R-project.org/package= caret (accessed on 7 December 2021).

57. Robin, X.; Turck, N.; Hainard, A.; Tiberti, N.; Lisacek, F.; Sanchez, J.C.; Müller, M. pROC: An open-source package for R and S+ to analyze and compare ROC curves. BMC Bioinform. 2011, 12, 77. [CrossRef]

58. Soon, P.S.H.; Libe, R.; Benn, D.E.; Gill, A.; Shaw, J.; Sywak, M.S.; Groussin, L.; Bertagna, X.; Gicquel, C.; Bertherat, J.; et al. Loss of heterozygosity of 17p13, with possible involvement of ACADVL and ALOX15B, in the pathogenesis of adrenocortical tumors. Ann. Surg. 2008, 247, 157-164. [CrossRef]

59. Bavelloni, A.; Ramazzotti, G.; Poli, A.; Piazzi, M.; Focaccia, E.; Blalock, W.; Faenza, I. MiRNA-210: A Current Overview. Anticancer Res. 2017, 37, 6511-6521.

60. Pouysségur, J.; Dayan, F.; Mazure, N.M. Hypoxia signalling in cancer and approaches to enforce tumour regression. Nature 2006, 441, 437-443. [CrossRef]

61. Semenza, G.L. Targeting HIF-1 for cancer therapy. Nat. Rev. Cancer 2003, 3, 721-732. [CrossRef]

62. Grosso, S.; Doyen, J.; Parks, S.K.; Bertero, T.; Paye, A.; Cardinaud, B.; Gounon, P.; Lacas-Gervais, S.; Noël, A.; Pouysségur, J.; et al. MiR-210 promotes a hypoxic phenotype and increases radioresistance in human lung cancer cell lines. Cell Death Dis. 2013, 4, e544. [CrossRef]

63. Nohata, N.; Hanazawa, T.; Kikkawa, N.; Mutallip, M.; Sakurai, D.; Fujimura, L.; Kawakami, K.; Chiyomaru, T.; Yoshino, H.; Enokida, H.; et al. Tumor suppressive microRNA-375 regulates oncogene AEG-1/MTDH in head and neck squamous cell carcinoma (HNSCC). J. Hum. Genet. 2011, 56, 595-601. [CrossRef] [PubMed]

64. Tsukamoto, Y.; Nakada, C.; Noguchi, T.; Tanigawa, M.; Nguyen, L.T.; Uchida, T.; Hijiya, N.; Matsuura, K.; Fujioka, T.; Seto, M.; et al MicroRNA-375 Is Downregulated in Gastric Carcinomas and Regulates Cell Survival by Targeting PDK1 and 14-3-3द. Cancer Res. 2010, 70, 2339-2349. [CrossRef] [PubMed]

65. Liu, A.M.; Poon, R.T.P.; Luk, J.M. MicroRNA-375 targets Hippo-signaling effector YAP in liver cancer and inhibits tumor properties. Biochem. Biophys. Res. Commun. 2010, 394, 623-627. [CrossRef] [PubMed]

66. Ding, L.; Xu, Y.; Zhang, W.; Deng, Y.; Si, M.; Du, Y.; Yao, H.; Liu, X.; Ke, Y.; Si, J.; et al. MiR-375 frequently downregulated in gastric cancer inhibits cell proliferation by targeting JAK2. Cell Res. 2010, 20, 784-793. [CrossRef]

67. Li, X.; Lin, R.; Li, J. Epigenetic silencing of microRNA-375 regulates PDK1 expression in esophageal cancer. Dig. Dis. Sci. 2011, 56, 2849-2856. [CrossRef]

68. Ladeiro, Y.; Couchy, G.; Balabaud, C.; Bioulac-Sage, P.; Pelletier, L.; Rebouissou, S.; Zucman-Rossi, J. MicroRNA profiling in hepatocellular tumors is associated with clinical features and oncogene/tumor suppressor gene mutations. Hepatology 2008, 47, 1955-1963. [CrossRef]

69. Tissier, F.; Cavard, C.; Groussin, L.; Perlemoine, K.; Fumey, G.; Hagneré, A.M.; René-Corail, F.; Jullian, E.; Gicquel, C.; Bertagna, X.; et al. Mutations of $\beta$-Catenin in Adrenocortical Tumors: Activation of the Wnt Signaling Pathway Is a Frequent Event in both Benign and Malignant Adrenocortical Tumors. Cancer Res. 2005, 65, 7622-7627. [CrossRef]

70. Berthon, A.; Martinez, A.; Bertherat, J.; Val, P. Wnt/ $\beta$-catenin signalling in adrenal physiology and tumour development. Mol. Cell. Endocrinol. 2012, 351, 87-95. [CrossRef]

71. Decmann, A.; Perge, P.; Nyíro, G.; Darvasi, O.; Likó, I.; Borka, K.; Micsik, T.; Tóth, Z.; Bancos, I.; Pezzani, R.; et al. MicroRNA Expression Profiling in Adrenal Myelolipoma. J. Clin. Endocrinol. Metab. 2018, 103, 3522-3530. [CrossRef]

72. Soon, P.S.H.; Gill, A.J.; Benn, D.E.; Clarkson, A.; Robinson, B.G.; McDonald, K.L.; Sidhu, S.B. Microarray gene expression and immunohistochemistry analyses of adrenocortical tumors identify IGF2 and Ki-67 as useful in differentiating carcinomas from adenomas. Endocr. Relat. Cancer 2009, 16, 573-583. [CrossRef]

73. De Fraipont, F.; El Atifi, M.; Cherradi, N.; Le Moigne, G.; Defaye, G.; Houlgatte, R.; Bertherat, J.; Bertagna, X.; Plouin, P.F.; Baudin, E.; et al. Gene Expression Profiling of Human Adrenocortical Tumors Using Complementary Deoxyribonucleic Acid 
Microarrays Identifies Several Candidate Genes as Markers of Malignancy. J. Clin. Endocrinol. Metab. 2005, 90, 1819-1829. [CrossRef]

74. Agosta, C.; Laugier, J.; Guyon, L.; Denis, J.; Bertherat, J.; Libé, R.; Boisson, B.; Sturm, N.; Feige, J.J.; Chabre, O.; et al. MiR-483-5p and miR-139-5p promote aggressiveness by targeting N-myc downstream-regulated gene family members in adrenocortical cancer. Int. J. Cancer 2018, 143, 944-957. [CrossRef]

75. Wang, L.; Shi, M.; Hou, S.; Ding, B.; Liu, L.; Ji, X.; Zhang, J.; Deng, Y. MiR-483-5p suppresses the proliferation of glioma cells via directly targeting ERK1. FEBS Lett. 2012, 586, 1312-1317. [CrossRef]

76. Liu, K.; He, B.; Xu, J.; Li, Y.; Guo, C.; Cai, Q.; Wang, S. miR-483-5p Targets MKNK1 to Suppress Wilms' Tumor Cell Proliferation and Apoptosis In Vitro and In Vivo. Med. Sci. Monit. 2019, 25, 1459. [CrossRef]

77. Zhao, J.J.; Yang, J.; Lin, J.; Yao, N.; Zhu, Y.; Zheng, J.; Xu, J.; Cheng, J.Q.; Lin, J.Y.; Ma, X. Identification of miRNAs associated with tumorigenesis of retinoblastoma by miRNA microarray analysis. Child's Nerv. Syst. 2009, 25, 13-20. [CrossRef]

78. Corbetta, S.; Vaira, V.; Guarnieri, V.; Scillitani, A.; Eller-Vainicher, C.; Ferrero, S.; Vicentini, L.; Chiodini, I.; Bisceglia, M.; BeckPeccoz, P.; et al. Differential expression of microRNAs in human parathyroid carcinomas compared with normal parathyroid tissue. Endocr. Relat. Cancer 2010, 17, 135-146. [CrossRef]

79. Sarkar, S.; Dey, B.K.; Dutta, A. MiR-322/424 and -503 Are Induced during Muscle Differentiation and Promote Cell Cycle Quiescence and Differentiation by Down-Regulation of Cdc25A. Mol. Biol. Cell 2010, 21, 2138. [CrossRef]

80. Forrest, A.R.R.; Kanamori-Katayama, M.; Tomaru, Y.; Lassmann, T.; Ninomiya, N.; Takahashi, Y.; De Hoon, M.J.L.; Kubosaki, A.; Kaiho, A.; Suzuki, M.; et al. Induction of microRNAs, mir-155, mir-222, mir-424 and mir-503, promotes monocytic differentiation through combinatorial regulation. Leukemia 2009, 24, 460-466. [CrossRef]

81. Vabalas, A.; Gowen, E.; Poliakoff, E.; Casson, A.J. Machine learning algorithm validation with a limited sample size. PLoS ONE 2019, 14, e0224365. [CrossRef] 